\title{
Expression of Voltage-Gated Potassium Channels Decreases Cellular Protein Tyrosine Phosphorylation
}

\author{
Todd C. Holmes, Kevin Berman, Jill E. Swartz, Daniel Dagan, and Irwin B. Levitan \\ Department of Biochemistry and Volen Center for Complex Systems, Brandeis University, \\ Waltham, Massachusetts 02254
}

\begin{abstract}
Protein tyrosine phosphorylation by endogenous and expressed tyrosine kinases is reduced markedly by the expression of functional voltage-gated potassium (Kv) channels. The levels of tyrosine kinase protein and cellular protein substrates are unaffected, consistent with a reduction in tyrosine phosphorylation that results from inhibition of protein tyrosine kinase activity. The attenuation of protein tyrosine phosphorylation is correlated with the gating properties of expressed wild-type and mutant Kv channels. Furthermore, cellular protein tyrosine
\end{abstract}

phosphorylation is reduced within minutes by acute treatment with the electrogenic potassium ionophore valinomycin. Because tyrosine phosphorylation in turn influences $\mathrm{Kv}$ channel activity, these results suggest that reciprocal modulatory interactions occur between Kv channel and protein tyrosine phosphorylation signaling pathways.

Key words: delayed-rectifier potassium channel; protein tyrosine kinase; src; epidermal growth factor receptor; modulation; phosphorylation
Protein tyrosine phosphorylation regulates a wide variety of cellular processes, including proliferation, differentiation, and survival. Steady-state cellular protein phosphotyrosine levels are regulated by the opposing activities of protein tyrosine kinases (PTKs) and protein tyrosine phosphatases (PTPases). Most cells exhibit low steady-state protein phosphotyrosine levels, which reflects the tight regulation of PTK activity and the relatively high ratio of the total specific activity of PTPases to PTKs (Hunter, 1995). PTK activity is modulated by many stimuli at the cell membrane, and an enormous amount of effort has been directed toward characterizing the signaling events that occur after the binding of growth factors, cytokines, neurotransmitters, and antigens to specific membrane receptors (June et al., 1990; Schlessinger and Ullrich, 1992; Erpel and Courtneidge, 1995; Hunter, 1995; Wan et al., 1996). Recent studies indicate that electrical signaling can influence PTK activity and protein tyrosine phosphorylation as well (Bading and Greenberg, 1991; Rusanescu et al., 1995; Olivotto et al., 1996; Siciliano et al., 1996).

The activity of voltage-gated potassium $(\mathrm{Kv})$ channels is essential for electrical excitability (Hille, 1992). Increased Kv channel density and outward potassium conductance lead to hyperpolarization of the cell membrane potential (Felipe et al., 1993; Becherer et al., 1996; Marom et al., 1996), whereas decreased potassium conductance causes depolarization (Leonard et al., 1992; Becherer et al., 1996; Panyi et al., 1996). Modulation of Kv channel activity alters cell membrane properties, and protein

Received June 11, 1997; revised Aug. 29, 1997; accepted Sept. 16, 1997.

This work was supported by a grant from the National Institutes of Health to I.B.L. and by a National Research Service Award fellowship award to T.C.H. We thank Debra Fadool, Richard Huganir, Louis Philipson, James Douglass, Morgan Sheng, and Richard Swanson for generously providing antibodies and cDNA constructs, Mark Bowlby for electrophysiological verification of the nonconducting mutant W386F Kv1.3, Manisha Desai for Kv1.4 and Kv1.5 current traces, and Chris Miller for insightful suggestions.

Correspondence should be addressed to Todd C. Holmes, Volen Center for Complex Systems, Brandeis University, Waltham, MA 02254.

Mr. Berman's present address: University of Texas, Southwestern Medical Center at Dallas, Harry Hines Boulevard, Dallas, TX 75235.

Dr. Dagan's permanent address: Bernard Katz Minerva Center, Cell Biophysics, P.O. Box 9697, Haifa 31096, Israel.

Copyright (C) 1997 Society for Neuroscience $\quad 0270-6474 / 97 / 178964-11 \$ 05.00 / 0$ phosphorylation is one of the best-characterized mechanisms of ion channel modulation (Levitan, 1994; Jonas and Kaczmarek, 1996). Recently, there has been rapid progress in characterizing the effects of tyrosine phosphorylation on $\mathrm{Kv}$ channels including the mammalian Shaker-like channels Kv1.2, Kv1.3, and Kv1.5 (Huang et al., 1993; Lev et al., 1995; Holmes et al., 1996a,b; Szabo et al., 1996; Fadool et al., 1997). The activity of Kv channels is often suppressed by tyrosine phosphorylation (Huang et al., 1993; Holmes et al., 1996a), and changes in channel kinetics are also observed (Fadool et al., 1997); these modulatory effects can be eliminated by mutation of specific tyrosine residues.

One intriguing aspect of tyrosine phosphorylation-induced modulation of $\mathrm{Kv}$ channel activity is that $\mathrm{Kv}$ channel activity may in turn influence PTK activity. Previous studies suggest that PTK activity and protein tyrosine phosphorylation are modulated by ion conductances and membrane depolarization (Bading and Greenberg, 1991; Vostal et al., 1991; Siciliano et al., 1994, 1996; Lev et al., 1995; Rusanescu et al., 1995; Yu et al., 1996) and that ion conductances can influence developmental events (Jones and Ribera, 1994; Spitzer, 1994). This raises the interesting possibility that reciprocal modulatory interactions might occur between $\mathrm{Kv}$ channels and PTKs or PTPases. We have addressed this question by heterologous expression of cloned $\mathrm{Kv}$ channels in human embryonic kidney (HEK 293) cells, because expressed channels determine the membrane current responses and strongly dominate the electrical properties of transfected cells (Marshall et al., 1995; Marom et al., 1996).

\section{MATERIALS AND METHODS}

cDNA expression vectors. All mammalian expression vectors used for these experiments contained the cytomegalovirus (CMV) promoter upstream from the coding region. The plasmid pRc-CMV (Invitrogen, San Diego, CA) was used as the control vector for all experiments. The cDNAs for $\mathrm{v}$-src kinase (v-src) and the human epidermal growth factor receptor (EGFr) were generously provided by Dr. Richard Huganir (Johns Hopkins University, Baltimore, MD). The Kv1.5, Kv1.4, and Kv1.3 vectors were generously provided by Dr. Louis Philipson (University of Chicago, Chicago, IL), by Dr. Morgan Sheng (Massachusetts General Hospital, Boston, MA), and by Dr. Richard Swanson (Merck, Sharp, and Dohme Research Laboratories, West Point, PA), respectively. Site-directed mutagenesis was used to construct five mutant Kv1.3 
channels in which Tyr or Trp residues were mutated to Phe (a triplet YYY111-113FFF, Y137F, W386F, Y449F, and Y479F). Single PCRs using a mutagenic primer and a wild-type primer were used to introduce the mutations. PCR incubations were run in a thermocycler (Twin Block System; Eri-Comp, San Diego, CA) using Taq polymerase (Promega, Madison, WI). PCR products were cut sequentially at appropriate restriction sites with a phenol and chloroform extraction and ethanol precipitation between cuts. An identical protocol was used to cut wildtype Kv1.3 in the pRc-CMV vector to construct a backbone. The desired pieces were gel purified (Gene-Clean II; BIO 101, La Jolla, CA) from $2 \%$ agarose gels, and the mutagenic inserts were ligated into the Kv1.3-pRcCMV backbone using T4 DNA ligase (Promega). The mutagenic insertions were confirmed by sequencing.

Cell culture and transfection procedures. HEK 293 cells were maintained in modified Eagle's medium (MEM) containing $2 \%$ penicillin and streptomycin and $10 \%$ fetal bovine serum (GIBCO-BRL, Gaithersburg, MD). Cells were grown to confluency (1 week), dissociated with trypsinEDTA and mechanical trituration, diluted in MEM to a concentration of $\sim 600$ cells $/ \mu \mathrm{l}$, and replated on Corning plastic dishes (Corning, NY). cDNA vectors were introduced into HEK 293 cells (Graham et al., 1977) by lipofectamine transfection (GIBCO-BRL). Briefly, cells were transfected 3-5 d after recovery from cell passage, at either 20-30\% (electrophysiology) or $70-80 \%$ (biochemistry) confluency. The amount of total cDNA used for transfection was the same for all control and experimental groups. Cells were transfected with either $10 \mu \mathrm{g}$ of DNA per $60 \mathrm{~mm}$ dish for biochemical or $1 \mu \mathrm{g}$ of DNA per $35 \mathrm{~mm}$ dish for electrophysiological experiments.

For Kv channel and PTK coexpression experiments, cells were cotransfected with a total of $10 \mu \mathrm{g}$ of DNA per $60 \mathrm{~mm}$ dish $(5 \mu \mathrm{g}$ of DNA of each construct coding for a Kv channel and PTKs; the Kv channel or PTK-alone groups were brought up to $10 \mu \mathrm{g}$ of DNA with the addition of $5 \mu \mathrm{g}$ of vector control cDNA). Cotransfection control cells were transfected with $10 \mu \mathrm{g}$ of vector DNA per $60 \mathrm{~mm}$ dish. Cells were incubated for $5 \mathrm{hr}$ with the lipofectamine and DNA mixture diluted in serum-reduced medium (OptiMEM; GIBCO-BRL). Transfection efficiency was monitored in parallel plates by staining for the $\beta$-galactosidase reaction product in Lac-Z expression plasmid-transfected cells. Staining efficiency (blue cells) normally ranged from 40 to $50 \%$ for biochemistry and 70 to $90 \%$ for electrophysiology experiments (Holmes et al., 1996a)

Pervanadate preparation and treatment. Pervanadate was prepared by a 2 min incubation of $100 \mathrm{~mm} \mathrm{Na} \mathrm{VO}_{4}$ and $\mathrm{H}_{2} \mathrm{O}_{2}$, followed by dilution to the appropriate concentration $\left(0-250 \mu \mathrm{M}\right.$ in $\left.0.0008 \% \mathrm{H}_{2} \mathrm{O}_{2}\right)$ in serumfree MEM (Bourgoin and Grinstein, 1992; Holmes et al., 1996a). Cells were incubated with pervanadate in MEM for the times indicated.

Valinomycin preparation and treatment. Cells were washed twice (2 $\mathrm{ml} /$ dish) with serum-free MEM. Valinomycin was prepared in a $5 \mathrm{mg} / \mathrm{ml}$ stock in ethanol and diluted 1:1000 in serum-free MEM. Valinomycintreated cells were preincubated in serum-free MEM containing valinomycin $(5 \mu \mathrm{g} / \mathrm{ml}+0.1 \%$ ethanol) for $10 \mathrm{~min}$. Control cells were preincubated in serum-free MEM containing $0.1 \%$ ethanol vehicle for $10 \mathrm{~min}$. All groups were treated with pervanadate for $30 \mathrm{~min}$. The pervanadate solutions contained either valinomycin $(5 \mu \mathrm{g} / \mathrm{ml})$ and ethanol vehicle $(0.1 \%)$ or ethanol vehicle $(0.1 \%)$ alone.

Cell lysis and immunoprecipitation. Cells were harvested $2 \mathrm{~d}$ after transfection by lysis in ice-cold $1 \%$ Triton X-100-modified immunoprecipitation buffer (Holmes et al., 1996a) containing protease and phosphatase inhibitors $(25 \mathrm{~mm}$ Tris, $\mathrm{pH} 7.5,150 \mathrm{~mm} \mathrm{NaCl}, 100 \mathrm{~mm} \mathrm{NaF}, 5 \mathrm{~mm}$ EDTA, $1 \mathrm{~mm} \mathrm{Na} \mathrm{VO}_{4}, 1 \%$ Triton X-100, $1 \mathrm{~mm}$ PMSF, $1 \mu \mathrm{g} / \mathrm{ml}$ leupeptin, and $2 \mu \mathrm{g} / \mathrm{ml}$ aprotinin). The cell lysates were clarified by centrif ugation $\left(15,000 \times g ; 5 \mathrm{~min} ; 4^{\circ} \mathrm{C}\right)$. To immunoprecipitate lysate proteins from the supernatant, we precleared the supernatant with $30 \mu \mathrm{l}$ of Protein A/G (Pierce, Rockford, IL) per ml of cell lysate for $1 \mathrm{hr}$ at $4^{\circ} \mathrm{C}$ and followed with overnight incubation with $5 \mu$ lof antibody per $\mathrm{ml}$ of cell lysate at $4^{\circ} \mathrm{C}$. The antibody and protein complexes were captured by incubation with $30 \mu \mathrm{l}$ of Protein A/G (Pierce) per ml of cell lysate for 1 $\mathrm{hr}$ at $4^{\circ} \mathrm{C}$. The immunoprecipitates were washed three times with ice-cold $0.1 \%$ Triton X-100-modified immunoprecipitation buffer (200 volumes of wash buffer per volume of immunoprecipitate pellet). Lysate samples and washed immunoprecipitates were diluted in SDS-gel loading buffer (Sambrook et al., 1989). Total protein levels per culture dish (determined by the Pierce BCA protein assay) were equivalent for all transfection conditions using coding DNA.

Western blot and autoradiogram procedures. Protein tyrosine phosphorylation was measured by Western blot analysis, using antibodies that specifically recognize phosphotyrosine. Proteins $(10 \mu \mathrm{g} /$ lane $)$ were sep- arated on $10 \%$ acrylamide gels by SDS-PAGE. The gels were processed with Coomassie brilliant blue dye, or silver stain, or were electrotransferred to nitrocellulose blots (Sambrook et al., 1989). The blots were blocked in 5\% nonfat milk and incubated overnight with primary antibody at $4^{\circ} \mathrm{C}$. They were then incubated with horseradish peroxidase (HRP)-conjugated secondary antibody (Amersham, Arlington Heights, IL) for $2 \mathrm{hr}$ at room temperature. Enhanced chemiluminescence (ECL; Amersham) exposure on XAR-2 film (Kodak, Rochester, NY) was used to visualize labeled protein. The magnitude of the signal is directly related to the amount of HRP-conjugated secondary antibody. The Coomassie blue- and silver-stained gels and film autoradiograms were analyzed by densitometry using a Bio-Rad Model GS-670 Imaging Densitometer (Hercules, CA). Relative densitometry values were determined to be linear by serial dilution of protein samples used for Western immunoblotting.

Tyrosine-phosphorylated proteins were detected by Western blot with the mouse monoclonal antibodies 4G10 (Upstate Biotechnology, Lake Placid, NY) and PY20 (Transduction Laboratories, Lexington, KY). Kv1.3 expression was verified by Western blot using rabbit polyclonal antisera generously provided by Dr. James Douglass (Cai and Douglass, 1993). EGFr expression was detected with a human-specific mouse monoclonal antibody (E12020; Transduction Laboratories). Src expression (expressed v-Src and endogenous c-Src) was detected with a mouse monoclonal antibody (MAb327; Oncogene Science, Cambridge, MA) and rabbit polyclonal antiserum (Upstate Biotechnology). All other chemicals used for Western blotting, immunoprecipitation, and electrophysiology were purchased from Sigma (St. Louis, MO).

Patch recording. Macroscopic currents in cell-attached membrane patches were recorded 24-72 hr after transfection using an Axopatch-1B amplifier (Axon Instruments, Foster City, CA). Cells were visualized at $40 \times$ magnification using a phase contrast water immersion lens (Zeiss, Thornwood, NY). The extracellular solution consisted of (in mM): 150 $\mathrm{KCl}, 10 \mathrm{HEPES}$, pH 7.5, 1 EGTA, and $0.5 \mathrm{MgCl}_{2}$; the pipette solution consisted of (in mM): $30 \mathrm{KCl}, 70 \mathrm{NaCl}, 2 \mathrm{CaCl}_{2}, 1$ EGTA, and 10 HEPES, pH 7.5. Electrodes were fabricated from Jencons glass (\#M15/ 10; Leighton Buzzard, Bedfordshire, England), fire-polished to $\sim 1 \mu \mathrm{m}$, and coated near the tip with beeswax to reduce the capacitance of the glass. Pipette resistances were between 9 and $14 \mathrm{M} \Omega$.

Cells were held at $-80 \mathrm{mV}$ and stepped to a pulse potential of $+40 \mathrm{mV}$ for a pulse duration of $1000 \mathrm{msec}$. Voltage signals were generated, and data were captured using a microstar DAP 800/2 board (Microstar Lab, Bellevue, WA). Data traces were linearly subtracted for leakage conductance.

Immunocytochemistry. Surface labeling of wild-type and mutant Kv1.3 was measured as described previously (Fadool et al., 1997). HEK 293 cells were plated on poly-D-lysine-coated glass coverslips and were transfected with control vector, Kv1.3, or W386F Kv1.3 cDNA. Two days after transfection, the cells were fixed lightly with $1 \%$ paraformaldehyde, washed with PBS, and incubated overnight at $4^{\circ} \mathrm{C}$ with anti-Kv1.3 extracellular epitope rabbit polyclonal antiserum (Cai and Douglass, 1993) (1:50 dilution with $10 \%$ normal goat serum). The cells were washed on the coverslips with PBS, incubated with secondary antibody (anti-rabbit $\mathrm{F}\left(\mathrm{ab}^{\prime}\right)_{2}$-FITC; $1: 1000 ; 30 \mathrm{~min}$ at $37^{\circ} \mathrm{C}$ ) (Tago, Burlingame, CA), and washed again with PBS. The coverslips were mounted on glass slides with Gelmount (Biomeda, Foster City, CA). Indirect immunofluorescent labeling was detected by scanning confocal microscopy (MRC-600; BioRad) using equal gain and aperture settings for all images. Parallel experiments using cell-impermeant rhodamine-conjugated phycoerythrin confirmed that Kv1.3 labeling was at the cell surface. No staining was observed under identical fixation conditions with another anti-Kv1.3 antiserum directed against an intracellular epitope (Fadool et al., 1997).

\section{RESULTS}

\section{Pervanadate-induced cellular protein tyrosine phosphorylation is attenuated by Kv1.3 expression}

We used heterologous expression of the cloned Kv1.3 channel to study the influence of $\mathrm{Kv}$ channel expression on protein tyrosine phosphorylation. The effect of Kv1.3 expression on endogenous PTK activity was examined by treating control and Kv1.3transfected HEK 293 cells with the specific membrane-permeant tyrosine phosphatase inhibitor pervanadate. Pervanadate inhibition of PTPase activity is half maximal at $15 \mu \mathrm{M}$ and approaches 
A

CELL LYSATES BLOT: Anti-PY

B
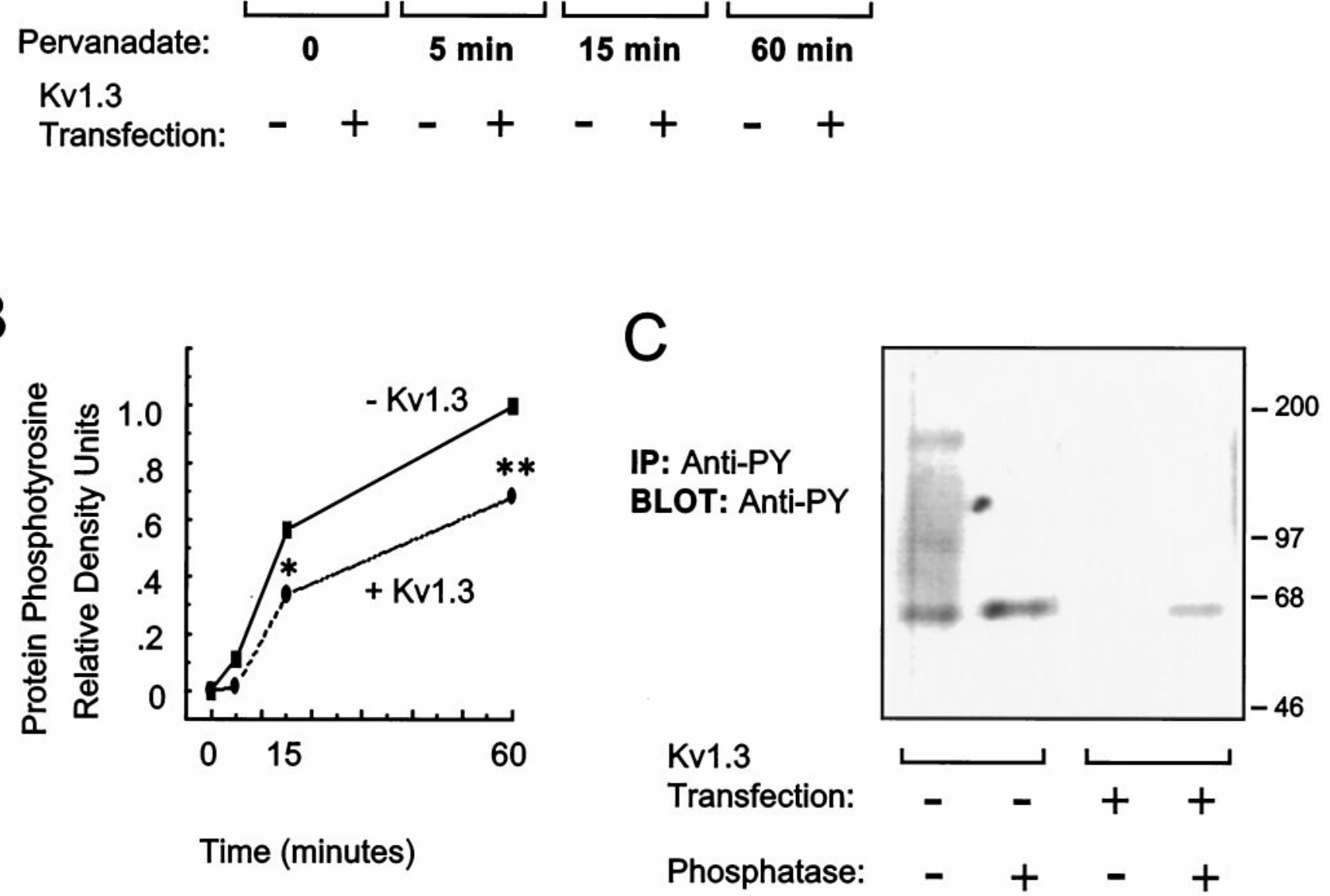

Figure 1. Kv1.3 expression decreases endogenous protein tyrosine phosphorylation in pervanadate-treated HEK 293 cells. Cells were transfected with cDNA for either control vector $(-)$ or Kv1.3 (+). Two days after transfection, cells were treated with the membrane-permeant tyrosine phosphatase inhibitor pervanadate $(250 \mu \mathrm{M} ; 0-60 \mathrm{~min})$. A, Cell lysates were prepared, and the lysate proteins were separated by SDS-PAGE and electrotransferred to nitrocellulose. Immunoblots were probed with anti-phosphotyrosine antibody (anti-PY). Primary antibody binding was visualized by incubation with a horseradish peroxidase-conjugated secondary antibody and ECL and autoradiography. $B$, Protein phosphotyrosine signal was quantified in each lane of the blot in $A$ by densitometry, and values are expressed relative to that in the pervanadate-treated lane, without Kv1.3 expression, at 60 min $(n=4$; ${ }^{*} p \leq 0.05$ and ${ }^{* *} p \leq 0.01$, Student's $t$ test). $C$, Tyrosine-phosphorylated proteins were immunoprecipitated (IP) using anti-phosphotyrosine antibody. Half of the IP samples were treated with alkaline phosphatase overnight $(+)$. All IP samples were separated by SDS-PAGE and electrotransferred to nitrocellulose. Immunoblots (Blot) were probed with another anti-phosphotyrosine antibody. An artifactual band of apparent molecular weight slightly greater than the major tyrosine-phosphorylated band is present in the alkaline phosphatase-treated samples.

saturation at $100 \mu \mathrm{M}$ (Bourgoin and Grinstein, 1992; Holmes et al., 1996a). HEK 293 cells were transfected with control or Kv1.3 vector and $2 \mathrm{~d}$ after transfection were treated with pervanadate (250 $\mu \mathrm{M}$ in serum-free medium; 0-60 min) or medium alone. Low basal protein phosphotyrosine levels in HEK 293 cell lysates are demonstrated by SDS-PAGE Western blot (Fig. 1A) using a monoclonal antibody that specifically recognizes phosphotyrosine. Faint bands at molecular weights of 180-190, 130, and 50-60 kDa can be detected after longer exposures. This faint signal can be amplified by immunoprecipitating tyrosinephosphorylated proteins with one anti-phosphotyrosine antibody, followed by SDS-PAGE and Western blot analysis of the immu- 


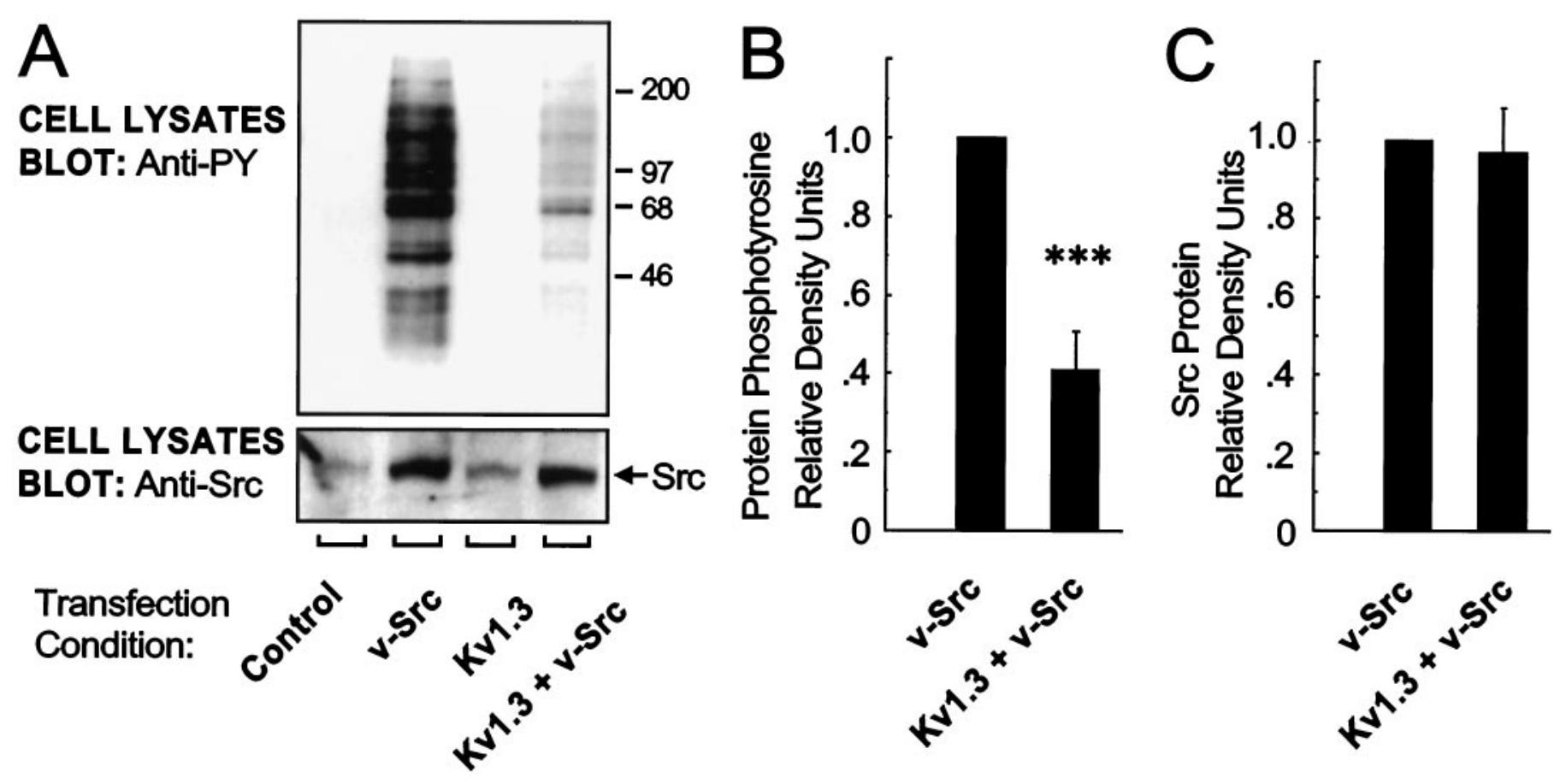

Figure 2. Kv1.3 coexpression decreases v-Src-induced protein tyrosine phosphorylation. HEK 293 cells were transfected with control, v-src, Kv1.3, or Kv1.3 together with v-src (cotransfection) vectors. $A$, Two days after transfection, cell lysates were prepared, and lysate proteins were separated by SDS-PAGE, transferred to nitrocellulose, and probed with anti-phosphotyrosine (top) or anti-Src (bottom) antibody. $B$, The protein phosphotyrosine signal was quantified by densitometry, and values are expressed relative to the v-Src lane $\left(n=10 ;{ }^{* * *} p \leq 0.005\right.$, Student's $t$ test). $C$, Expressed Src protein was quantified by densitometry, and values are expressed relative to the v-Src lane $(n=10)$.

noprecipitates with another anti-phosphotyrosine antibody (Fig. $1 C)$. Basal protein phosphotyrosine levels are decreased in immunoprecipitates prepared from Kv1.3-transfected cells compared with immunoprecipitates prepared from control vectortransfected cells (Fig. $1 C$ ). The protein phosphotyrosine signal is not detectable after alkaline phosphatase treatment of the immunoprecipitates (Fig. $1 C$; note that an artifactual band is present in the alkaline phosphatase-treated samples). Pervanadate treatment increases protein phosphotyrosine levels in a timedependent manner (Wallace, 1995; Holmes et al., 1996a). Kv1.3 expression attenuates pervanadate-induced protein tyrosine phosphorylation measured after 15 and $60 \mathrm{~min}$ of pervanadate treatment (Fig. 1A,B). The relative attenuation of protein tyrosine phosphorylation by Kv1.3 expression seems to be greater for the shorter time points (Fig. $1 B$ ). This could reflect saturation of phosphorylation sites at later times. Alternatively, this might reflect decreased potassium conductance over time, because tyrosine phosphorylation-induced suppression of $\mathrm{Kv}$ channel activity increases over time (Holmes et al., 1996a). The Kv1.3mediated decrease of pervanadate-induced protein tyrosine phosphorylation does not seem to be caused by decreased levels of total protein, as measured by total protein assay and Coomassie blue staining of lysate protein separated by SDS-PAGE (data not shown). The effect of Kv1.3 expression on the protein levels of several prominent endogenous protein kinases, including src family kinases, the EGFr, and protein kinase C, was measured. Kv1.3 expression does not affect the protein levels of these kinases (e.g., Fig. 2A).

v-Src-induced cellular protein tyrosine phosphorylation is attenuated by Kv1.3 expression

To determine whether the expression of Kv channels can decrease protein phosphotyrosine levels induced by an expressed PTK, we measured protein phosphotyrosine levels in cell lysates prepared from cells expressing the constitutively active nonreceptor PTK v-Src, with and without Kv1.3 expression. HEK 293 cells were transfected with control, Kv1.3, or v-src vectors or with the Kv1.3 and v-src vectors together (cotransfection). Cells were harvested $2 \mathrm{~d}$ after transfection, and cell lysates were used for SDS-PAGE Western blot using anti-phosphotyrosine or anti-Src monoclonal antibodies. v-Src expression induces large increases in cell protein phosphotyrosine levels (Fig. 2A, top), and this v-Src-induced protein tyrosine phosphorylation is reduced substantially by Kv1.3 cotransfection (Fig. $2 A$, top, $B$ ). In contrast, endogenous and expressed Src protein levels are unaffected by Kv1.3 expression (Fig. 2A, bottom, $C$ ).

\section{The gating properties of mutant Kv1.3 channels determine their ability to attenuate v-Src-induced protein tyrosine phosphorylation}

The marked attenuation of protein tyrosine phosphorylation by Kv1.3 expression raises the possibility that increased potassium conductance and cell hyperpolarization influence PTK activity. To eliminate the possibility that expression of any protein nonspecifically attenuates protein tyrosine phosphorylation, we coexpressed v-Src with a nonconducting mutant Kv1.3 channel. If $\mathrm{Kv}$ channel conductance is a critical variable for attenuating protein tyrosine phosphorylation, then one would predict that the expression of nonconducting $\mathrm{Kv}$ channels would have little effect on $\mathrm{v}$-Src-induced protein tyrosine phosphorylation. In contrast, the expression of high-conducting Kv channels would be expected to greatly attenuate protein tyrosine phosphorylation. The conduction properties of $\mathrm{Kv}$ channels can be changed dramatically by single point mutations (Perozo et al., 1993).

We constructed a nonconducting mutant Kv1.3 channel (W386F Kv1.3). Mutation at this site in the putative pore of the 
related Shaker channel yields a nonconducting channel that is expressed and is targeted efficiently to the cell membrane (Perozo et al., 1993). Patch-clamp analysis shows no detectable current over endogenous levels in cell-attached membrane patches on HEK 293 cells transfected with W386F Kv1.3 vector (Fig. 3A), whereas macroscopic current is apparent in patches on HEK 293 cells transfected with wild-type Kv1.3 (Fig. $3 A$ ). The absence of W386F Kv1.3 current is not because of lack of channel protein expression, because Kv1.3 and $\mathrm{W} 386 \mathrm{~F}$ Kv1.3 protein levels are similar under all transfection conditions (Fig. 3B). Furthermore, scanning confocal immunocytochemical analysis of HEK 293 cells transfected with Kv1.3 or W386F Kv1.3 and labeled with antibodies directed against an extracellular epitope of these channels shows that both channels are expressed efficiently at the cell surface (Fig. 3C). The effects of expression of Kv1.3 and W386F Kv1.3 on cellular protein tyrosine phosphorylation were compared. In contrast to the large attenuation of v-Src-induced protein tyrosine phosphorylation by Kv1.3, nonconducting W386F Kv1.3 does not affect protein phosphotyrosine levels (Fig. 3D,E). In a related set of experiments, HEK 293 cells were transfected with control, Kv1.3, v-src, or the Kv1.3 and v-src vectors together (cotransfection) in the presence of brefeldin A, which arrests the transport of newly synthesized proteins in the early Golgi stacks and prevents protein transport to the plasma membrane (Klausner et al., 1992). Kv1.3 expression does not affect v-Src-induced protein phosphotyrosine levels after brefeldin A treatment (data not shown). Thus, protein tyrosine phosphorylation attenuation by $\mathrm{Kv}$ channel expression requires the presence of functional conducting $\mathrm{Kv}$ channels in the plasma membrane.

The activity of Kv channels is suppressed by tyrosine phosphorylation (Huang et al., 1993; Holmes et al., 1996a,b; Szabo et al., 1996; Fadool et al., 1997). It is notable that mutant channels lacking specific tyrosine phosphorylation sites are resistant to phosphorylation-induced current suppression (Huang et al., 1993; Holmes et al., 1996a; Fadool et al., 1997). We have characterized a set of Y-to-F mutant Kv1.3 channels that are less suppressed than are the wild-type Kv1.3, when they are coexpressed with $\mathrm{v}$-Src in HEK 293 cells (Fadool et al., 1997). These mutant channels are expressed to the same extent as wild-type Kv1.3, and their basal biophysical properties are indistinguishable from those of the wild-type channel (Fadool et al., 1997). HEK 293 cells were transfected with control vector; v-src vector; Kv1.3 vector; vectors encoding one of the mutant Kv1.3 channels YYY111-113FFF Kv1.3, Y137F Kv1.3, Y449F Kv1.3, or Y479F $\mathrm{Kv1.3}$; or the $\mathrm{v}$-src vector together with wild-type or mutant channel vector. Cells were harvested $2 \mathrm{~d}$ after transfection, and cell lysates were used for SDS-PAGE Western blot analysis probed with anti-phosphotyrosine monoclonal antibody. The Yto-F mutant Kv1.3 channels attenuate v-Src-induced protein tyrosine phosphorylation to a greater extent than does the wildtype Kv1.3 channel (Fig. 4A,B).

To test further the effects of Kv channel expression on v-Srcinduced protein tyrosine phosphorylation, we coexpressed $\mathrm{v}-\mathrm{Src}$ with other $\mathrm{Kv}$ channels that exhibit different gating properties. Kv1.4 inactivates rapidly, after channel opening, by a "ball and chain" mechanism (Chandy and Gutman, 1995); in contrast, Kv1.5 exhibits very slow inactivation (Fig. $5 A$ ). The coexpression of the rapidly inactivating Kv1.4 channel has little effect on $\mathrm{v}$-Src-induced protein tyrosine phosphorylation (Fig. $5 B, C$ ). In contrast, coexpression of the slowly inactivating Kv1.5 channel strongly suppresses $\mathrm{v}$-Src-induced protein tyrosine phosphorylation (Fig. $5 B, C$ ).

\section{Tyrosine phosphorylation of the EGF receptor is attenuated by Kv channel expression}

Kv channel expression decreases pervanadate- or v-Src-induced tyrosine phosphorylation of many proteins, including a prominent protein with a molecular weight of $185-190 \mathrm{kDa}$. This size range includes the EGFr (Cadena and Gill, 1992). To determine the effect of $\mathrm{Kv}$ channel expression on an identified protein, we coexpressed the human EGFr with Kv1.3 and measured protein levels and tyrosine phosphorylation of the EGFr with and without EGF treatment. Cells were treated with EGF $(10 \mathrm{ng} / \mathrm{ml}$ in serumfree medium; $60 \mathrm{~min}$ ) or with serum-free medium and were harvested immediately after EGF treatment. Kv1.3 coexpression does not affect the protein levels of EGFr (Fig. 6A, top). The EGFr expressed alone is strongly tyrosine phosphorylated in the absence of exogenous EGF (Fig. 6A, bottom), as is observed frequently for expressed receptor PTKs (Chen et al., 1997). The tyrosine phosphorylation of the EGFr expressed alone is increased over basal levels by exogenous EGF treatment. Kv1.3 coexpression markedly decreases the tyrosine phosphorylation of the EGFr with and without EGF treatment (Fig. 6 $\mathrm{A}$, bottom, $\mathrm{B}$ ).

\section{Acute treatment with valinomycin decreases protein tyrosine phosphorylation}

In the experiments reported here, Kv channel-induced attenuation of protein tyrosine phosphorylation is measured $2 \mathrm{~d}$ after transfection. To determine the acute effect on protein phosphotyrosine levels of increasing potassium conductance, we treated pervanadate-stimulated HEK 293 cells with the electrogenic potassium-specific ionophore valinomycin (Lindoy, 1988; Woolley et al., 1995). Valinomycin allows rapid outflow of potassium out of cells down the potassium concentration gradient, thus acutely mimicking the effects of increased $\mathrm{Kv}$ channel expression. Pervanadate-induced protein tyrosine phosphorylation is attenuated by acute treatment with valinomycin (Fig. $7 A, B ; 5 \mu \mathrm{g}$ of valinomycin $/ \mathrm{ml}$ of serum-free medium $+250 \mu \mathrm{M}$ pervanadate; 30 min). Thus, protein tyrosine phosphorylation mediated by endogenous PTKs is reduced by an acute treatment that increases potassium conductance.

\section{DISCUSSION}

Previous studies indicate that membrane depolarization increases protein tyrosine phosphorylation (Stratton et al., 1991; Woodrow et al., 1992; Siciliano et al., 1994). We show here that treatments that induce membrane hyperpolarization, such as expression of $\mathrm{Kv}$ channels or electrogenic potassium ionophore treatment, markedly attenuate protein tyrosine phosphorylation catalyzed by endogenous and coexpressed PTKs. The regulation of protein tyrosine phosphorylation by $\mathrm{Kv}$ channel activity is of particular interest, because it has been shown that $\mathrm{Kv}$ channel activity is modulated by tyrosine phosphorylation (Huang et al., 1993; Holmes et al., 1996a,b; Szabo et al., 1996; Fadool et al., 1997).

Decreases in protein phosphotyrosine levels could reflect decreased activity of PTKs or increased activity of PTPases. To distinguish between these two possibilities, we measured the effects of $\mathrm{Kv}$ channel expression or acute electrogenic potassium ionophore treatment on protein phosphotyrosine levels, under conditions that strongly inhibit PTPase activity. Kv channel expression or acute valinomycin treatment attenuate pervanadateinduced protein tyrosine phosphorylation. These experiments suggest that $\mathrm{Kv}$ channel expression influences the activity of PTKs, although they do not completely eliminate the possibility that Kv channel expression could increase PTPase activity even 


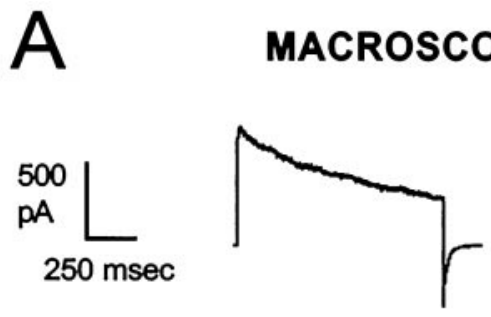

Transfection Condition:
Kv1.3
W386F Kv1.3

Non-Conducting
B

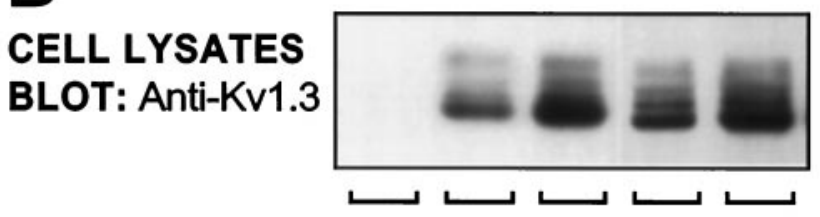

Transfection

Condition:

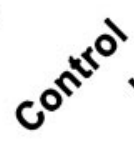<smiles>C[Si]1[C-]C=C1</smiles>

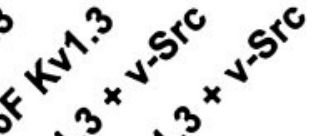

\section{SCANNING CONFOCAL IMMUNO- FLUORESCENCE MICROSCOPY}

SIGNAL: Anti-Kv1.3 extracellular epitope

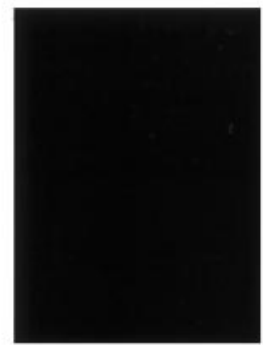

Control

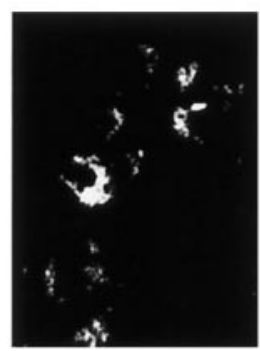

$\mathrm{Kv} 1.3$

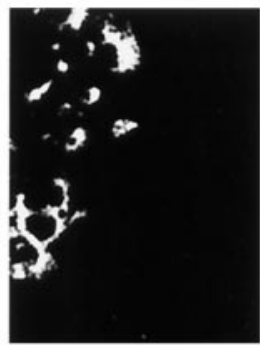

W386F Kv1.3

Transfection Condition:

D

CELL LYSATES

BLOT: Anti-PY

Transfection
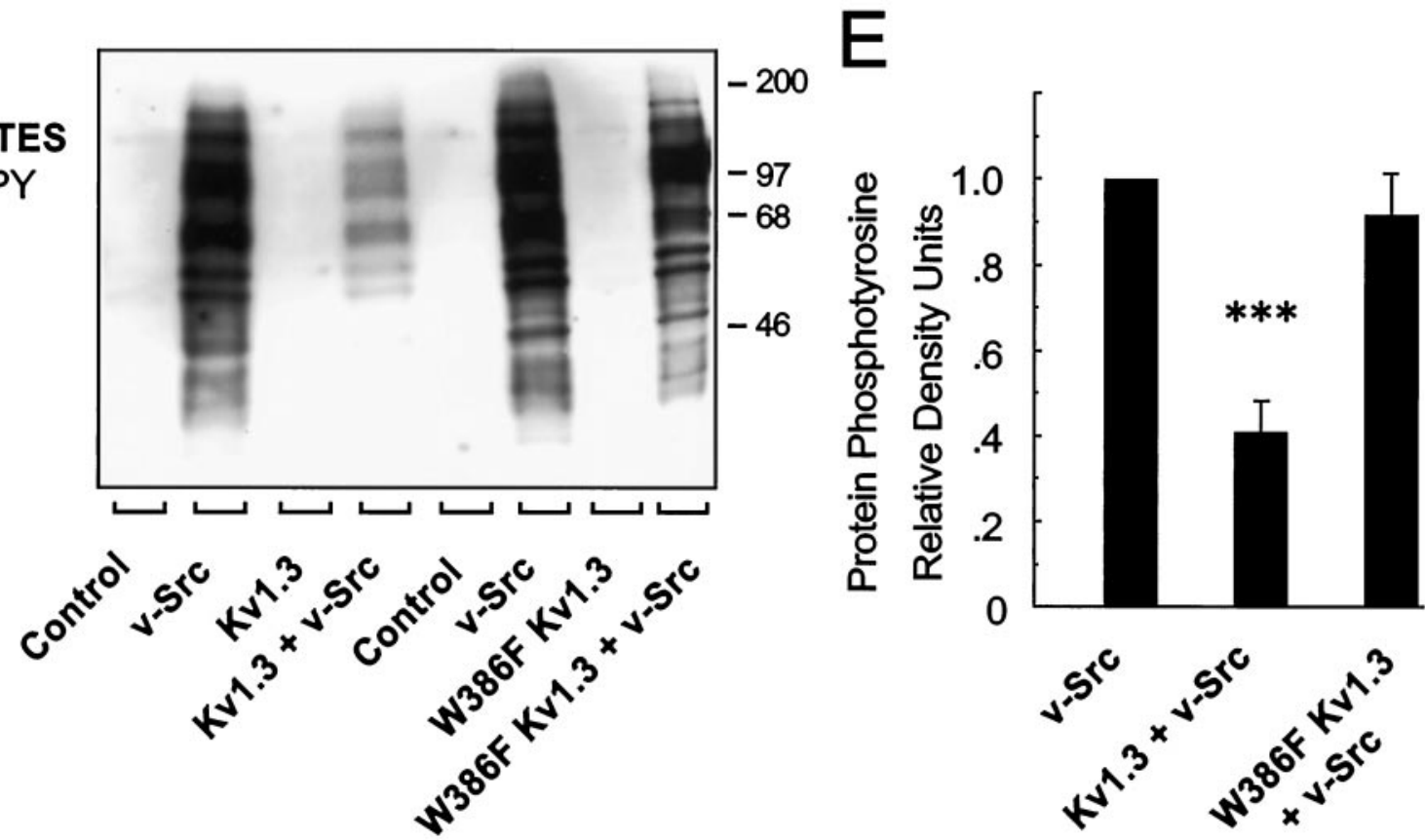

Figure 3. Nonconducting mutant Kv1.3 channel expression does not affect v-Src-induced protein tyrosine phosphorylation. HEK 293 cells were transfected with control, v-src, Kv1.3, W386F Kv1.3, Kv1.3 together with v-src, or W386F Kv1.3 together with v-src vectors. $A$, Cell-attached patch recordings were made $2 \mathrm{~d}$ after transfection. Currents evoked by depolarizing voltage pulses to $+40 \mathrm{mV}$ are shown for wild-type Kv1.3 and nonconducting mutant $\mathrm{W} 386 \mathrm{~F} \mathrm{Kv} 1.3(n=10)$. B, Two days after transfection, cell lysates were prepared, and lysate proteins were separated by SDS-PAGE, transferred to nitrocellulose, and probed with anti-Kv1.3 antibody. $C$, Cell surface labeling of Kv1.3 and W386F Kv1.3 was measured by indirect immunofluorescence scanning confocal microscopy, under nonpermeabilizing fixation conditions $(n=6)$. $D$, Immunoblots prepared as described in $B$ were probed with anti-phosphotyrosine antibody. $E$, The protein phosphotyrosine signal in $D$ was quantified by densitometry; values are expressed relative to the v-Src lane ( $n=7 ; * * * \leq 0.005$, Student's $t$ test). 

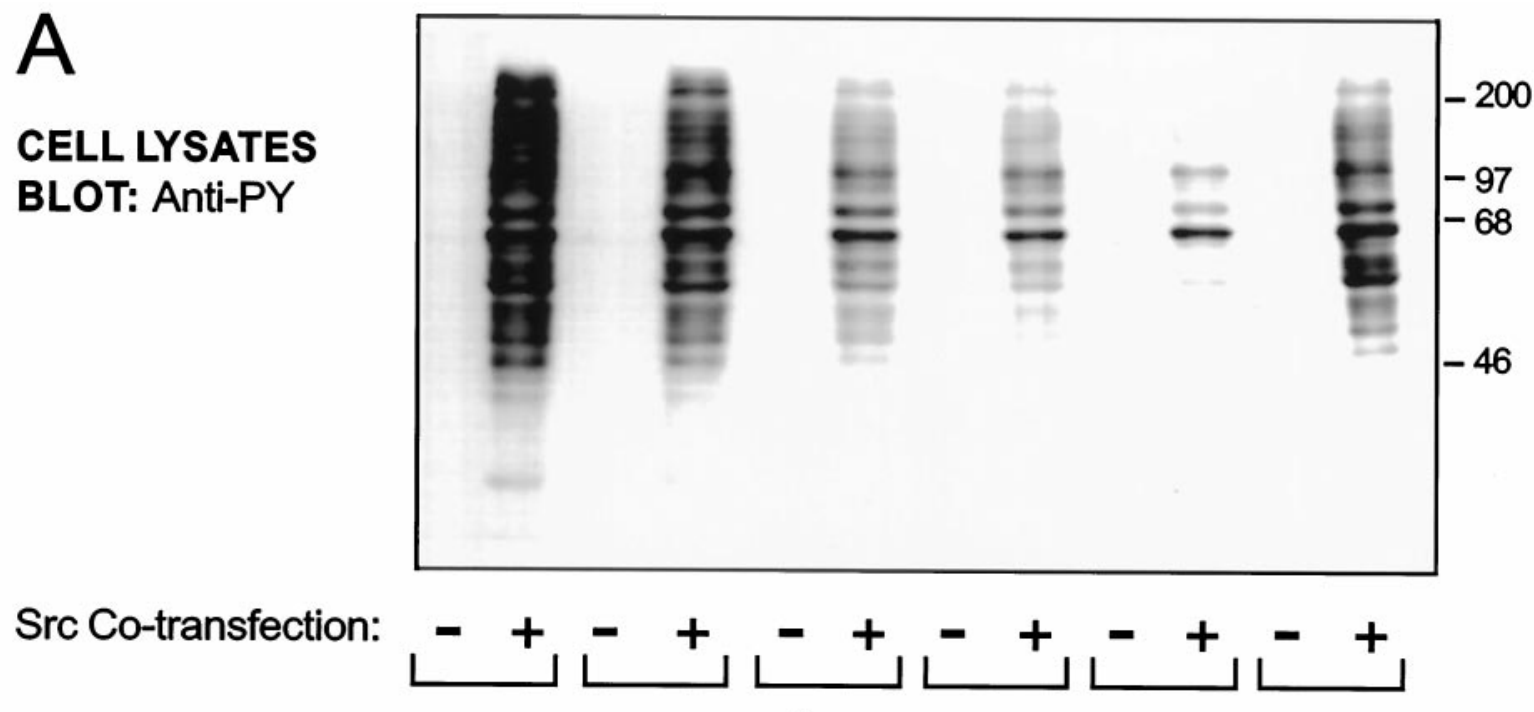

Channel:

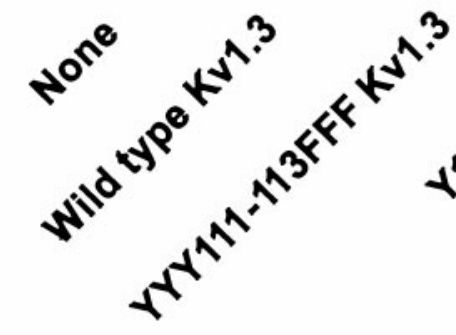

B

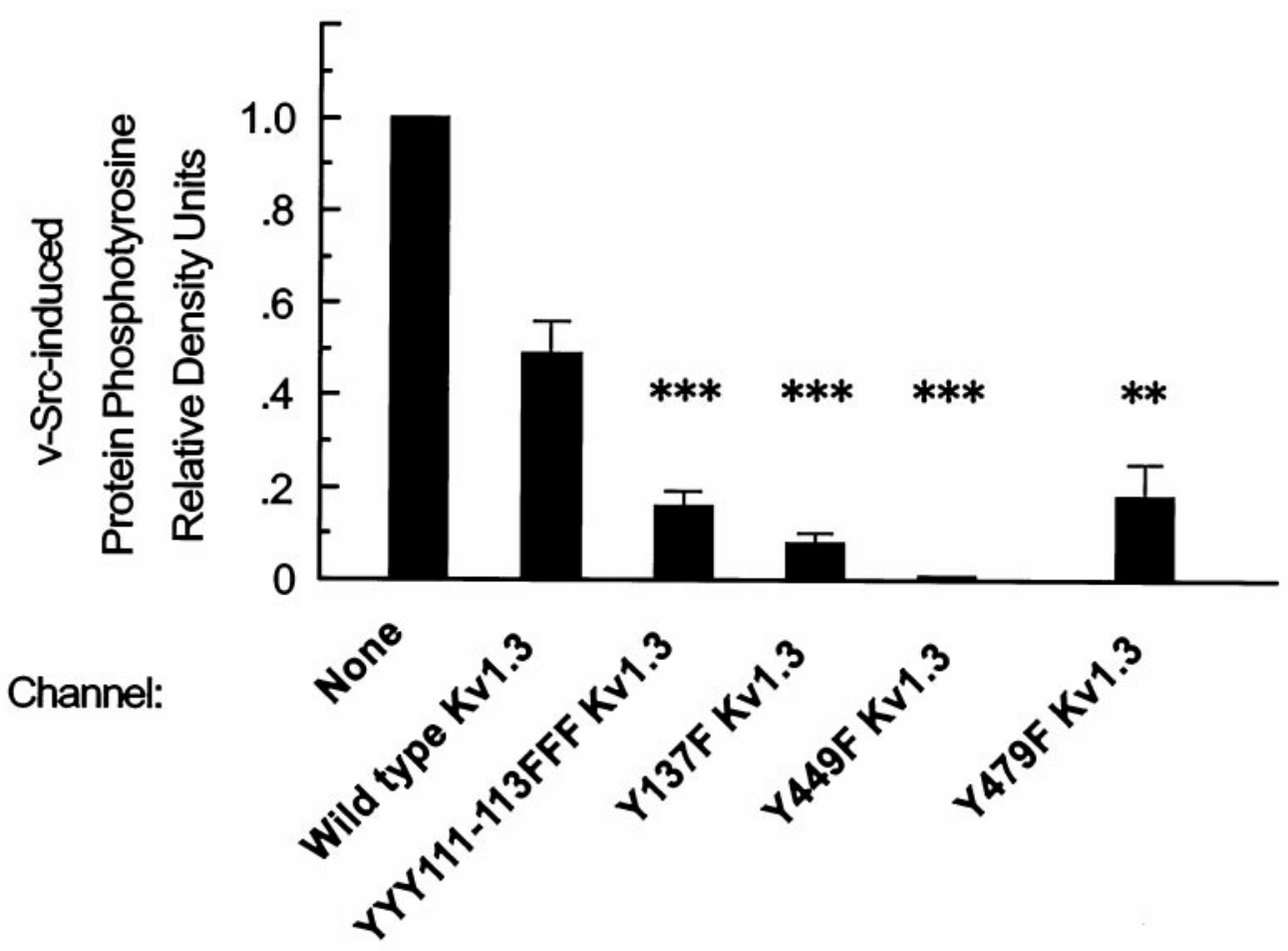

Figure 4. Coexpression of tyrosine mutant Kv1.3 channels decreases v-Src-induced protein tyrosine phosphorylation. $A$, HEK 293 cells were transfected with control vector; v-src vector; Kv1.3 vector; a vector encoding one of the mutant Kv1.3 channels YYY111-113FFF Kv1.3, Y137F Kv1.3, Y449F Kv1.3, or Y479F Kv1.3; or the v-src vector together with wild-type (+) or mutant Kv1.3 (-) vector (cotransfection). Cells were harvested $2 \mathrm{~d}$ after transfection, and cell lysates were used for SDS-PAGE Western blotting using anti-phosphotyrosine antibody. $B$, The protein phosphotyrosine signal was quantified by densitometry, and values are expressed relative to the v-Src lane (range of $n, 4-9 ;{ }^{* *} p \leq 0.01$ and ${ }^{* * *} p \leq 0.005$, Student's $t$ test). The statistical comparison is between the wild-type channel and the various Y-to-F mutant constructs. 


\section{A MACROSCOPIC CURRENT B}

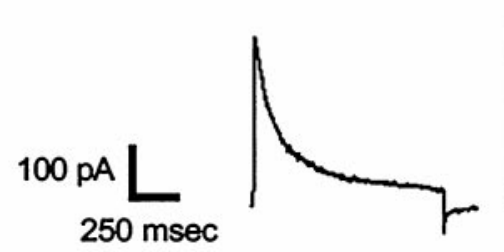

Transfection Condition: Kv1.4

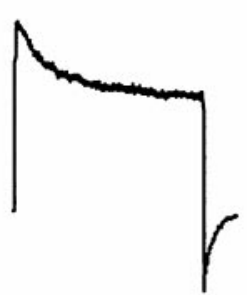

Kv1.5
CELL LYSATES BLOT: Anti-PY
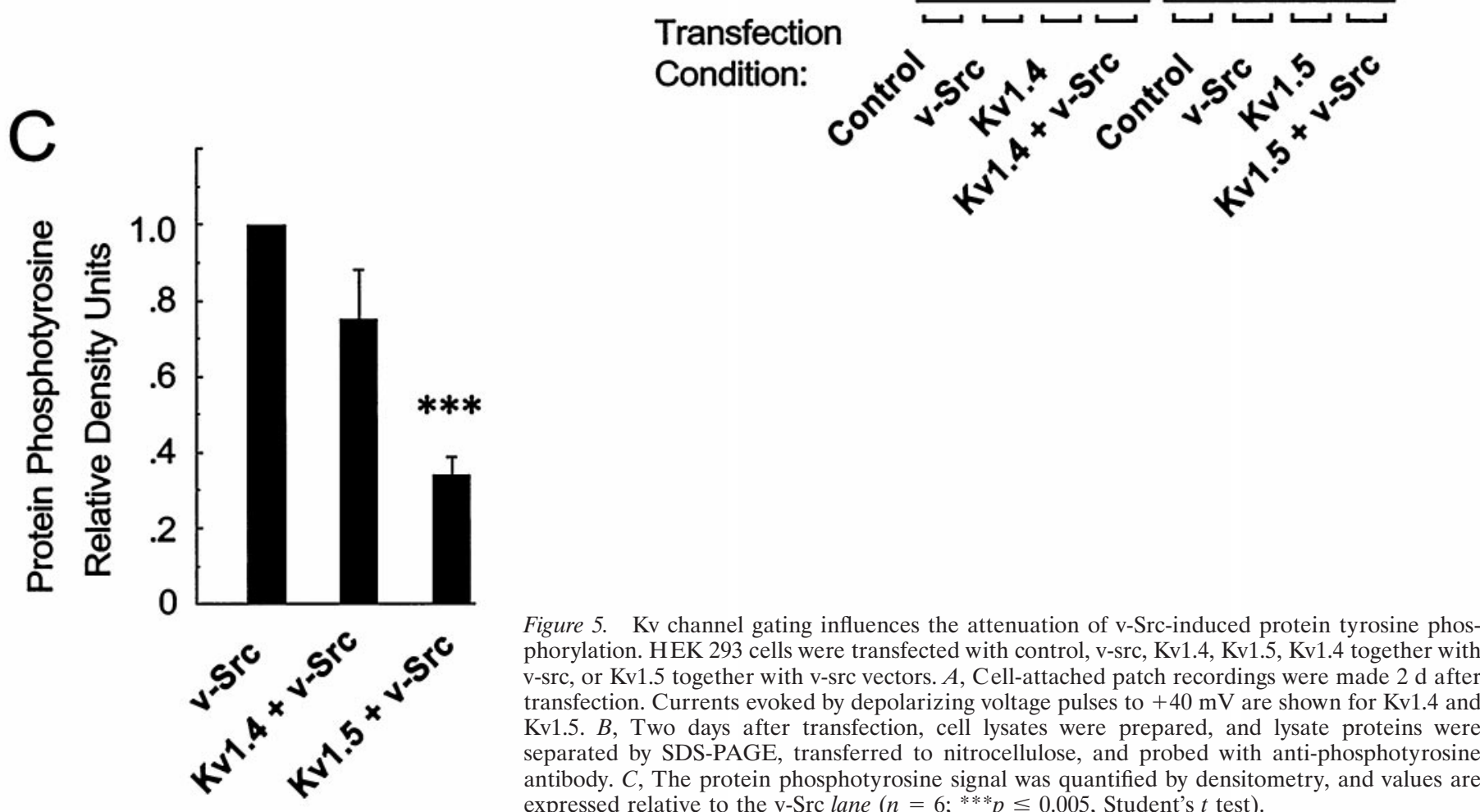

Figure 5. Kv channel gating influences the attenuation of v-Src-induced protein tyrosine phosphorylation. HEK 293 cells were transfected with control, v-src, Kv1.4, Kv1.5, Kv1.4 together with v-src, or Kv1.5 together with v-src vectors. $A$, Cell-attached patch recordings were made $2 \mathrm{~d}$ after transfection. Currents evoked by depolarizing voltage pulses to $+40 \mathrm{mV}$ are shown for Kv1.4 and Kv1.5. $B$, Two days after transfection, cell lysates were prepared, and lysate proteins were separated by SDS-PAGE, transferred to nitrocellulose, and probed with anti-phosphotyrosine antibody. $C$, The protein phosphotyrosine signal was quantified by densitometry, and values are expressed relative to the $\mathrm{v}-\mathrm{Src}$ lane $\left(n=6 ;{ }^{* * *} p \leq 0.005\right.$, Student's $t$ test).

in the presence of pervanadate. The observed Kv channelinduced decrease in protein tyrosine phosphorylation does not result from decreases in PTK protein or protein substrate levels, consistent with the idea that it reflects changes in the in vivo activity of PTKs. Although it is possible that Kv channel expression could lower cell ATP levels, the $K_{m}$ of PTKs for ATP is several orders of magnitude below cellular levels of ATP. Thus, regulation of protein phosphotyrosine levels by ATP availability seems unlikely.

To determine whether increased potassium conductance is responsible for the $\mathrm{Kv}$ channel-induced attenuation of protein tyrosine phosphorylation, we examined the effects of expressing a nonconducting mutant $\mathrm{Kv}$ channel. In contrast to the robust attenuation of protein phosphotyrosine levels by wild-type Kv1.3, the expression of nonconducting W386F Kv1.3 has no effect on protein phosphotyrosine levels. To determine further whether Kv channel expression is required at the cell membrane to attenuate protein phosphotyrosine levels, we coexpressed v-Src and Kv1.3 in the presence of brefeldin A. Kv1.3 expression does not attenuate protein phosphotyrosine levels under these conditions that arrest the transport of the channel to the cell membrane. These results show that the expression of functional $\mathrm{Kv}$ channels at the plasma membrane is required to decrease protein phosphotyrosine levels and indicate the importance of potassium conductance for this phenomenon.

$\mathrm{Kv}$ channel activity is in turn decreased by tyrosine phosphorylation (Huang et al., 1993; Holmes et al., 1996a,b; Szabo et al., 1996; Fadool et al., 1997). This tyrosine phosphorylation-induced decrease of $\mathrm{Kv}$ channel activity is less in mutant $\mathrm{Kv}$ channels that lack one or more tyrosine phosphorylation sites (Huang et al., 1993; Holmes et al., 1996a; Fadool et al., 1997). Thus cells expressing mutant Kv channels that lack tyrosine phosphorylation sites exhibit larger currents than do wild-type Kv channels, under conditions that promote tyrosine phosphorylation (Huang et al., 1993; Holmes et al., 1996a; Fadool et al., 1997). If Kv channel and PTK activities are reciprocally coupled, then the expression of phosphorylation-resistant Kv channels should lead to greater attenuation of PTK activity. Consistent with this prediction, we find that the magnitude of the Kv channel-induced attenuation of protein phosphotyrosine levels is greater with mutant channels that are resistant to phosphorylation-induced suppression. Further evidence supporting the importance of $\mathrm{Kv}$ channel-gating 
A

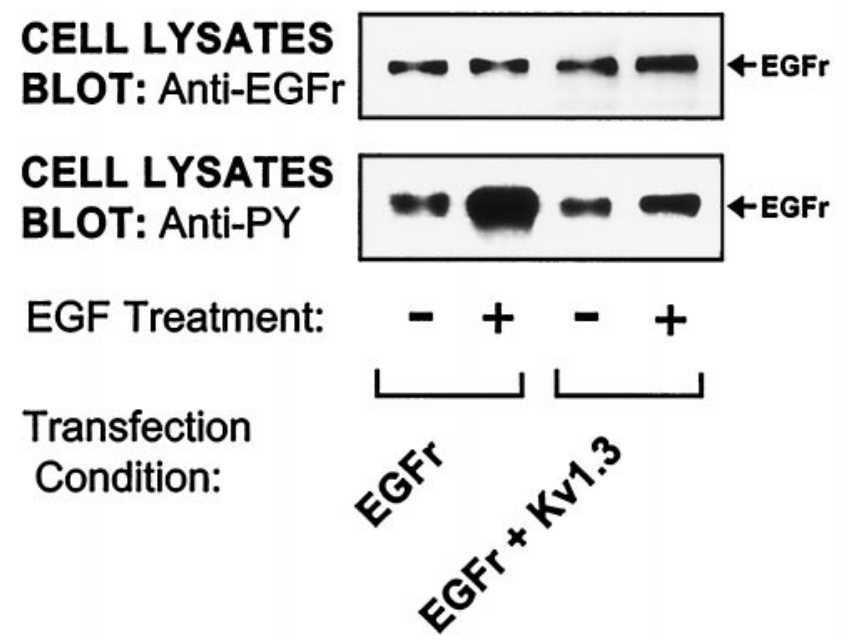

B

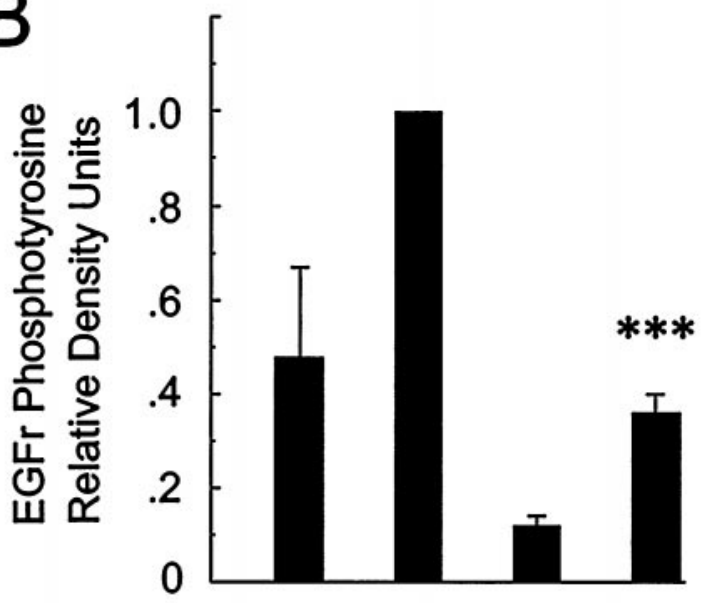

EGF

Treatment:

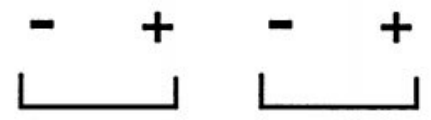

Transfection Condition:
A

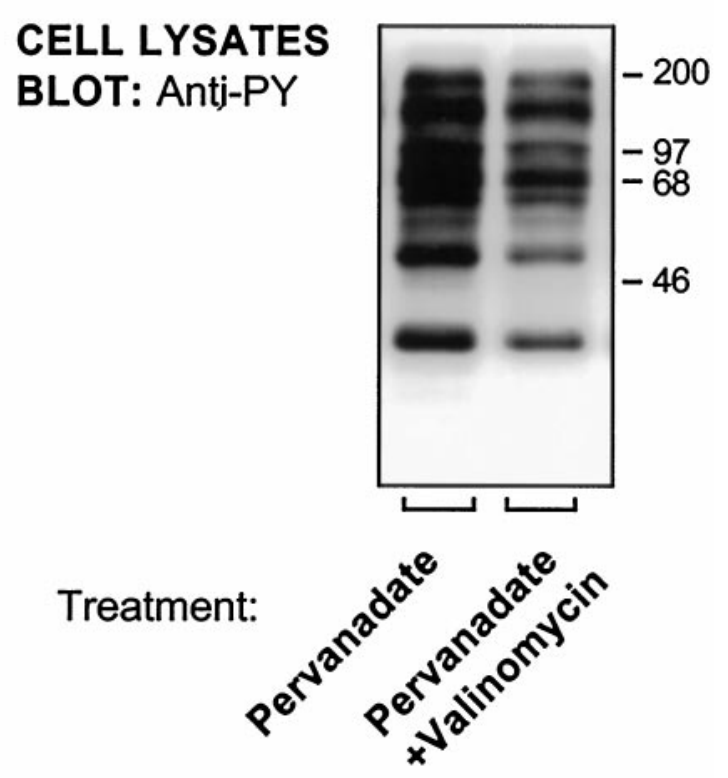

B

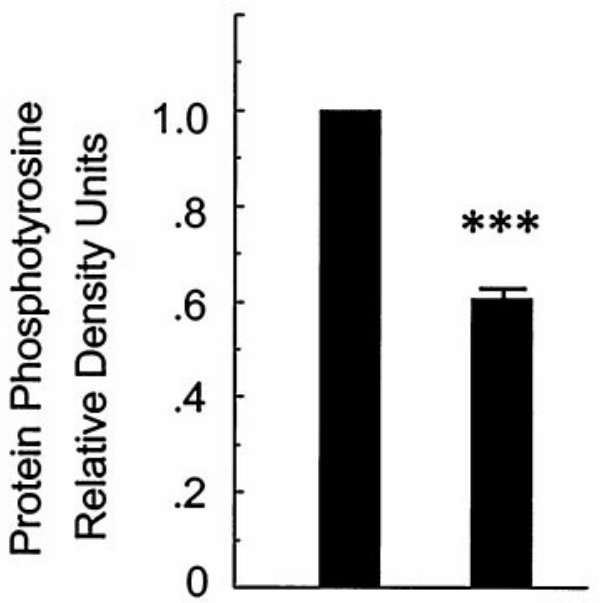

\section{Pervanadate \\ Valinomycin}

Figure 6. EGF receptor tyrosine phosphorylation is decreased by Kv1.3 coexpression. HEK 293 cells were transfected with control, EGFr, or Kv1.3 together with EGFr vectors. $A$, Two days after transfection, cells were treated with EGF $(+)$ or serum-free medium $(-)$. Cell lysates were prepared, and lysate proteins were separated by SDS-PAGE, transferrec to nitrocellulose, and probed with anti-EGFr (top) or antiphosphotyrosine (bottom) antibody. B, EGFr expression levels and protein phosphotyrosine signals were quantified in each lane by densitometry. EGFr phosphotyrosine values were normalized to EGFr protein levels (EGFr phosphotyrosine/EGFr protein) and expressed relative to the $\operatorname{EGFr}(+E G F)$ lane $(n=6 ; * * p \leq 0.005$, Student's $t$ test $)$.
Figure 7. Pervanadate-induced protein phosphotyrosine levels decrease after acute treatment with the electrogenic potassium ionophore valinomycin. $A$, Valinomycin-treated (+) HEK 293 cells were preincubated in serum-free medium containing valinomycin $(5 \mu \mathrm{g} / \mathrm{ml}+0.1 \%$ ethanol) for $10 \mathrm{~min}$ and then treated with pervanadate $(250 \mu \mathrm{M} ; 30 \mathrm{~min})$ in the continued presence of valinomycin. Control cells [without valinomycin $(-)]$ were preincubated and pervanadate-treated with serum-free medium containing $0.1 \%$ ethanol vehicle. After pervanadate treatment $(+)$, cell lysates were prepared, and lysate proteins were separated by SDS-PAGE, transferred to nitrocellulose, and probed with anti-phosphotyrosine antibody. $B$, Protein phosphotyrosine signals were quantified in each lane by densitometry, and values are expressed relative to the pervanadate without valinomycin condition $\left(n=6 ;{ }^{* *} p \leq 0.005\right.$, Student's $t$ test $)$. 
properties on protein tyrosine phosphorylation comes from experiments comparing the effects of rapidly and slowly inactivating Kv channels (Kv1.4 and Kv1.5). The expression of slowly inactivating Kv1.5 markedly attenuates protein phosphotyrosine levels, in contrast to the modest effects of expressing rapidly inactivating Kv1.4. Although we cannot exclude the possibility that some other difference between Kv1.4 and Kv1.5 contributes to this finding, these results show that the gating properties of expressed $\mathrm{Kv}$ channels correlate with their ability to attenuate protein phosphotyrosine levels. It is of interest that expression of Kv1.5 but not Kv1.4 results in a large hyperpolarization of the cell membrane (Felipe et al., 1993), consistent with the idea that tyrosine phosphorylation level is coupled to the membrane potential. However we cannot exclude the possibility that other mechanisms, for example, changes in intracellular potassium concentration, contribute to the attenuation of tyrosine phosphorylation.

The tyrosine phosphorylation level of many proteins decreases after Kv channel expression. The EGFr is one of these proteins. This is of particular interest, because the activity of the EGFr and other PTKs is strongly linked to cell proliferation (Schlessinger and Ullrich, 1992), and Kv channel overexpression decreases the number of neurons that differentiate (Jones and Ribera, 1994). It is noteworthy that it is difficult to establish stable cell lines constitutively expressing $\mathrm{Kv}$ channels, perhaps because of impaired proliferation of $\mathrm{Kv}$ channel-expressing cells (Koren et al., 1990; Suzuki et al., 1996).

Heterologous Kv channel expression peaks 2 d after transfection (Shi et al., 1994; Holmes et al., 1996a). It is conceivable that changes in protein phosphotyrosine levels reflect relatively longterm cellular compensatory events, including changes in gene expression, that could occur over days. To address this issue, we examined protein phosphotyrosine levels after acute treatment with the electrogenic potassium ionophore valinomycin, which rapidly increases potassium conductance (Lindoy, 1988; Woolley et al., 1995). Acute valinomycin treatment attenuates protein tyrosine phosphorylation mediated by endogenous PTKs. These data suggest strongly that the in vivo activity of some PTKs is sensitive to potassium conductance and the cell resting potential.

The present results add to the growing body of evidence that protein tyrosine phosphorylation is modulated by ion conductances and cell membrane potential (Bading and Greenberg, 1991; Vostal et al., 1991; Siciliano et al., 1994, 1996; Lev et al., 1995; Rusanescu et al., 1995; Yu et al., 1996). Previous studies have shown that depolarization elevates PTK activity and protein phosphotyrosine levels. Src kinase is activated by depolarization in PC12 cells (Rusanescu et al., 1995), and Src kinase activity and expression are increased in $\mathrm{Ca}^{2+}$-differentiated keratinocytes (Zhao et al., 1992). The proline-rich tyrosine kinase $2 /$ cell adhesion kinase $\beta$ is activated by calcium influx and depolarization in transfected HEK 293 cells, PC12 cells, and hippocampal neurons (Lev et al., 1995; Siciliano et al., 1996). In contrast to these earlier studies that use treatments that cause depolarization and $\mathrm{Ca}^{2+}$ influx, we have examined the effects on protein phosphotyrosine levels of treatments that cause cell hyperpolarization by expressing the mammalian Shaker-like Kv channels Kv1.3, Kv1.4, and Kv1.5. The results indicate that several different conditions that promote outward potassium flux decrease cellular protein tyrosine phosphorylation.

The presence of reciprocal modulation between Kv channels and protein tyrosine phosphorylation suggests the possibility of dual inhibition between Kv channel electrical signaling and PTK signaling. There are interesting implications of coupling ion chan- nel modulation and protein tyrosine phosphorylation regulation. In the present case, under conditions of low basal $\mathrm{Kv}$ channel phosphorylation, the opening of $\mathrm{Kv}$ channels would tend to dampen weak protein tyrosine phosphorylation signals. In contrast, under conditions of increased PTK activation, driven by an external stimulus such as a neurotransmitter or neurotrophic factor, increased tyrosine phosphorylation of Kv channels would lead to less channel activity and a consequent relief of Kv channel inhibition of protein tyrosine phosphorylation. Continuing feedback of this type could then rapidly increase protein tyrosine phosphorylation. Such dual-inhibition signaling between Kv channels and protein tyrosine phosphorylation could mediate rapid switch-like behaviors of both Kv channel and PTK activity.

These results are provocative in light of other lines of evidence that link ion channel modulation and regulation of protein tyrosine phosphorylation. Tyrosine phosphorylation increases NMDA receptor activity (Wang and Salter, 1994; Yu et al., 1997); in turn, NMDA receptor activation and glutamate treatment increase protein tyrosine phosphorylation (Bading and Greenberg, 1991; Siciliano et al., 1996). Voltage-gated L-type $\mathrm{Ca}^{2+}$ channels are activated by PTKs as well (Cataldi et al., 1996). These results suggest the possibility of dual-activation signaling between NMDA receptor/Ca ${ }^{2+}$ channels and protein tyrosine phosphorylation, whereas the present results indicate dualinhibition signaling between $\mathrm{Kv}$ channels and protein tyrosine phosphorylation. Similar reciprocal coupling may exist between ion channels and serine and threonine kinases and phosphatases. Candidate examples include couples between the type II $\mathrm{Ca}^{2+}$ and calmodulin-dependent protein kinase and voltage-gated $\mathrm{Ca}^{2+}$ channel activities (Hell et al., 1994; Xiao et al., 1994) and between calcineurin phosphatase and voltage-gated $\mathrm{Ca}^{2+}$ channel activities (Armstrong, 1989). The presence of dualmodulatory electrical and phosphorylation signaling may be important for tuning biochemical and electrical signaling events that influence biological functions such as synaptic plasticity. It will be of interest to determine the molecular mechanisms and cellular consequences of dynamic interactions between ion channelmediated electrical signaling and protein tyrosine phosphorylation signaling.

\section{REFERENCES}

Armstrong DL (1989) Calcium channel regulation by calcineurin, a $\mathrm{Ca}^{2+}$ activated phosphatase in mammalian brain. Trends Neurosci 12:1-10.

Bading H, Greenberg ME (1991) Stimulation of protein tyrosine phosphorylation by NMDA receptor activation. Science 253:912-914.

Becherer U, Rodeau J-L, Feltz A (1996) Resting potential of rat cerebellar granule cells during early maturation in vitro. J Neurobiol 32:11-21.

Bourgoin S, Grinstein S (1992) Peroxides of vanadate induce activation of phospholipase D in HL-60 cells. J Biol Chem 267:11908-11916.

Cadena DL, Gill GN (1992) Receptor tyrosine kinases. FASEB J 6:2332-2337.

Cai Y-C, Douglass J (1993) In vivo and in vitro phosphorylation of the T lymphocyte type $n$ (Kv1.3) potassium channel. J Biol Chem 268:23720-23727.

Cataldi M, Taglialatela M, Guerriero S, Amoroso S, Lombardi G, di Renzo G, Annunziato L (1996) Protein-tyrosine kinases activate while protein-tyrosine phosphatases inhibit L-type calcium channel activity in pituitary $\mathrm{GH}_{3}$ cells. J Biol Chem 271:9441-9446.

Chandy KG, Gutman GA (1995) Voltage-gated potassium channel genes. In: Handbook of receptors and channels: ligand and voltagegated ion channels (North RA, ed), pp 1-71. Boca Raton, FL: CRC.

Chen LI, Webster MK, Meyer AN, Donoghue DJ (1997) Transmembrane domain sequence requirements of activation of the $185^{\mathrm{c}-\mathrm{neu}}$ receptor tyrosine kinase. J Cell Biol 137:619-631. 
Erpel T, Courtneidge SA (1995) Src family protein tyrosine kinases and cellular signal transduction pathways. Curr Biol 7:176-182.

Fadool DA, Holmes TC, Berman K, Dagan D, Levitan IB (1997) Tyrosine phosphorylation modulates current amplitude and kinetics of a neuronal voltage-gated potassium channel. J Neurophysiol 78:1563-1573.

Felipe A, Snyders DJ, Deal KK, Tamkun MM (1993) Influence of cloned voltage-gated $\mathrm{K}^{+}$channel expression on alanine transport, $\mathrm{Rb}^{+}$ uptake, and cell volume. Am J Physiol 265:C1230-C1238.

Graham FL, Smiley J, Russell WC, Narin G (1977) Characteristics of a human cell line transformed by DNA from human adenovirus type 5 . J Gen Virol 36:59-74.

Hell JW, Appleyard SM, Yokoyama CT, Warner C, Catterall WA (1994) Differential phosphorylation of two size forms of the N-type calcium channel $\alpha 1$ subunit which have different $\mathrm{COOH}$ termini. J Biol Chem 269:7390-7396.

Hille B (1992) Ionic channels of excitable membranes, Ed 2. Sunderland, MA: Sinauer.

Holmes TC, Fadool DA, Levitan IB (1996a) Tyrosine phosphorylation of the Kv1.3 potassium channel. J Neurosci 16:1581-1590.

Holmes TC, Fadool DA, Ren R, Levitan IB (1996b) Direct association of Src tyrosine kinase with the human Kv1.5 potassium channel mediated by src homology 3 domain. Science 274:2089-2091.

Huang X-Y, Morielli AD, Peralta EG (1993) Tyrosine kinasedependent suppression of a potassium channel by the $G$ proteincoupled $\mathrm{m} 1$ muscarinic acetylcholine receptor. Cell 75:1145-1156.

Hunter T (1995) Protein kinases and phosphatases: the yin and yang of protein phosphorylation and signalling. Cell 80:225-236.

Jonas EA, Kaczmarek LK (1996) Regulation of potassium channels by protein kinases. Curr Opin Neurobiol 6:318-323.

Jones SM, Ribera AB (1994) Overexpression of a potassium channel gene perturbs neural differentiation. J Neurosci 14:2789-2799.

June CH, Fletcher MC, Ledbetter JA, Schieven GL, Siegel JN, Phillips AF, Samelson LE (1990) Inhibition of tyrosine phosphorylation prevents T-cell receptor-mediated signal transduction. Proc Natl Acad Sci USA 87:7722-7726.

Klausner RD, Donaldson JG, Lippincott-Schwartz J (1992) Brefeldin A: insights into the control of membrane traffic and organelle structure. J Cell Biol 116:1071-1080.

Koren G, Liman ER, Logothetis DW, Nadal-Ginard B, Hess P (1990) Gating mechanism of a cloned potassium channel expressed in frog oocytes and mammalian cells. Neuron 4:39-51.

Leonard RJ, Garcia ML, Slaughter RS, Reuben JP (1992) Selective blockers of voltage-gated $\mathrm{K}^{+}$channels depolarize human $\mathrm{T}$ lymphocytes: mechanism of the antiproliferative effect of charybdotoxin. Proc Natl Acad Sci USA 89:10094-10098.

Lev S, Moreno H, Martinez R, Canoll P, Peles E, Musacchio JM, Plowman GD, Rudy B, Schlessinger J (1995) Protein tyrosine kinase PYK2 involved in $\mathrm{Ca}^{2+}$-induced regulation of ion channel and MAP kinase functions. Nature 376:737-745.

Levitan IB (1994) Modulation of ion channels by protein phosphorylation and dephosphorylation. Annu Rev Physiol 56:193-212.

Lindoy LF (1988) The natural macrocycles. In: The chemistry of macrocyclic ligand complexes (Lindoy LF, ed), p 225. Cambridge, UK: Cambridge University.

Marom S, Salman H, Lyakhov V, Braun E (1996) Effects of density and gating of delayed-rectifier potassium channels on resting membrane potential and its fluctuations. J Membr Biol 154:267-274.

Marshall J, Molloy R, Moss GWJ, Howe JR, Hughes TE (1995) The jellyfish green fluorescent protein: a new tool for studying ion channel expression and function. Neuron 14:211-215.

Olivotto M, Arcangelli A, Carla M, Wanke E (1996) Electric fields at the plasma membrane level: a neglected element in the mechanisms of cell signalling. Bioessays 18:495-504.

Panyi G, Gaspar R, Krasznai Z, ter Horst JJ, Ameloot M, Aszalos A, Steels P, Damjanovich S (1996) Immunosuppressors inhibit voltagegated potassium channels in human peripheral blood lymphocytes. Biochem Biophys Res Commun 221:254-258.
Perozo E, MacKinnon R, Bezanilla F, Stefani E (1993) Gating currents from a nonconducting mutant reveal open-closed conformations in Shaker $\mathrm{K}^{+}$channels. Neuron 11:353-358.

Rusanescu G, Qi H, Thomas SM, Brugge JS, Halegoua S (1995) Calcium influx induces neurite growth through a src-ras signaling cassette. Neuron 15:1415-1425.

Sambrook J, Fritsch EF, Maniatas T (1989) Molecular cloning: a laboratory manual. New York: Cold Spring Harbor Laboratory.

Schlessinger J, Ullrich A (1992) Growth factor signaling by receptor tyrosine kinases. Neuron 9:383-391.

Shi G, Kleinklaus AK, Marrion NV, Trimmer JS (1994) Properties of $\mathrm{Kv} 2.1 \mathrm{~K}^{+}$channels expressed in transfected mammalian cells. J Biol Chem 269:23204-23211.

Siciliano JC, Gelman M, Girault J (1994) Depolarization and neurotransmitters increase neuronal protein tyrosine phosphorylation. J Neurochem 62:950-959.

Siciliano JC, Toutant M, Derkinderen P, Sasaki T, Girault J (1996) Differential regulation of proline-rich tyrosine kinase $2 /$ cell adhesion kinase $\beta(\mathrm{PYK} 2 / \mathrm{CAK} \beta)$ and $\mathrm{pp} 125^{\mathrm{FAK}}$ by glutamate and depolarization in rat hippocampus. J Biol Chem 271:28942-28946.

Spitzer NC (1994) Spontaneous $\mathrm{Ca}^{2+}$ spikes and waves in embryonic neurons: signaling systems for differentiation. Trends Neurosci 17:115-118.

Stratton KR, Worley PF, Litz JS, Parsons SJ, Huganir RL, Baraban JM (1991) Electroconvulsive treatment induces a rapid and transient increase in tyrosine phosphorylation of a 40-kilodalton protein associated with microtubule-associated protein kinase 2 activity. J Neurochem 56:147-152.

Suzuki M, Murata M, Ikeda M, Miyoshi T, Imai M (1996) Electrophysiological characterization of RACTK1 $\mathrm{K}^{+}$channel in stable cell line. Am J Physiol 270:C964-C968.

Szabo I, Gulbins E, Apfel H, Zhang X, Barth P, Busch AE, Schlottmann K, Pongs O, Lang F (1996) Tyrosine phosphorylation-dependent suppression of a voltage-gated $\mathrm{K}^{+}$channel in $\mathrm{T}$ lymphocytes upon fas stimulation. J Biol Chem 271:20465-20469.

Vostal JG, Jackson WL, Shulman NR (1991) Cytosolic and stored calcium antagonistically control tyrosine phosphorylation of specific platelet proteins. J Biol Chem 266:16911-16916.

Wallace BG (1995) Regulation of the interaction of nicotinic acetylcholine receptors with the cytoskeleton by agrin-activated protein tyrosine kinase. J Cell Biol 128:1121-1129.

Wan Y, Kurosaki T, Huang X-Y (1996) Tyrosine kinases in activation of the MAP kinase cascade by G-protein-coupled receptors. Nature 380:541-544.

Wang YT, Salter MW (1994) Regulation of NMDA receptors by tyrosine kinases and phosphatases. Nature 369:233-235.

Woodrow S, Bissoon N, Gurd JW (1992) Depolarization-dependent tyrosine phosphorylation in rat brain synaptosomes. J Neurochem 59:857-862.

Woolley GA, Pfeiffer DR, Deber CM (1995) Use of ionophores for manipulating intracellular ion concentrations. In: Measurement and manipulation of intracellular ions (Kracier J, Dixon SJ, eds), pp 52-68. San Diego: Academic.

Xiao R-P, Cheng H, Lederer WJ, Suzuki T, Lakatta EG (1994) Dual regulation of $\mathrm{Ca}^{2+}$ /calmodulin-dependent kinase II activity by membrane voltage and by calcium influx. Proc Natl Acad Sci USA 91:9659-9663.

Yu H, Li X, Marchetto GS, Dy R, Hunter D, Calvo B, Dawson TL, Wilm M, Anderegg RJ, Graves LM, Earp HS (1996) Activation of a novel calcium-dependent protein-tyrosine kinase. J Biol Chem 271: 29993-29998.

Yu XM, Askalan R, Kiel GJ, Salter MW (1997) NMDA channel regulation by channel-associated protein tyrosine kinase src. Science 275:674-678.

Zhao Y, Sudol M, Hanafusa H, Krueger J (1992) Increased tyrosine kinase activity of c-Src during calcium-induced keratinocyte differentiation. Proc Natl Acad Sci USA 89:8298-8302. 